\title{
Brand Culture: Trade Marks, Marketing and Consumption
}

\author{
Jonathan E. Schroeder ${ }^{1}$ \\ in \\ Interdisciplinary Perspectives on Trade Marks \\ Jane Ginsburg, Lionel Bently, and Jennifer Davis (eds.) \\ Cambridge: Cambridge University Press
}

forthcoming, 2007

University of Exeter

Discussion Papers in Management

Paper number 07/13

ISSN 1472-2939

\footnotetext{
${ }^{1}$ Professor of Marketing, School of Business and Economics, University of Exeter. Thanks to David Vaver for his energetic, playful and intellectually rich response to this paper, and also to Jennifer Davis, Graeme Dinwoodie, Lionel Bently, Jane Ginsburg and Bronwyn Parry for comments and encouragement. I also acknowledge financial support from the Jan Wallanders and Tom Hedelius Foundation.
} 
Brand Culture: Trade Marks, Marketing and Consumption

\section{DRAFT}

Visual images constitute much corporate communication about products, economic performance, and social responsibility, and also inform governmental efforts to create positive attitudes for citizens, consumers, and organizations. Brand image, corporate image, advertising images, and images of identity all depend upon compelling visual imagery. Variously referred to as the attention economy, the aesthetic economy, and the experience economy, this visual turn in marketing may call for new perspectives and research approaches. How do image communicate? What does the production and consumption of images mean for marketing and society? How does the handling of images in the allied fields of visual studies, art history, film theory, design management, and corporate identity shed light on the relationships between visual processes and consumption?

This chapter discusses methodological and theoretical issues of visual images as they pertain to brands via interdisciplinary research examples and exemplars. I place visual issues within a broader theoretical perspective of brand culture - the cultural dimensions or codes of brands - history, images, myths, art, theatre - that influence brand meaning in the marketplace. Visual consumer research cuts across methodological and topical boundary lines - the possibilities and problems of visual approaches encompass experimental and interpretive realms, and include such varied topics as information processing, image interpretation, and research techniques.

\section{The Image}


Visual images exist within a distinctive socio-legal environment - unlike textual or verbal statements, such as product claims or political promises, pictures cannot generally be held to be true or false - images often elude empirical verification. Thus, images are especially amenable to help strategists avoid being held accountable for false or misleading claims. For example, cigarette manufacturers have learned not to make text-based claims about their products, relying instead on visual imagery such as the lone cowboy.

Many battles of the brands take place within the visual domain. Design, in particular, depends upon visual understanding and aesthetic expertise. The Web mandates visualizing almost every aspect of corporate strategy, operations, and communication; web design has brought visual issues into the mainstream of strategic thinking, and spurred research and thinking about perception and preference of visual displays. Images - including brand images, corporate images, and Websites - constitute much corporate communication about products, economic performance, and corporate identity. ${ }^{1}$

From the consumer perspective, visual experiences dominate the Web, as they navigate through a computer-mediated environment almost entirely dependent upon their sense of sight. Photography remains a key component of many information technologies digital incorporation of scanned photographic images helped transform the Internet into what it is today. Photography, in turn, was heavily influenced by the older traditions of painting in

\footnotetext{
1 'Image' has often been opposed to 'substance' in marketing theory, as in wider intellectual discussions. For emerging notions about the role of the image in the economy and marketing, see, for example, see Scott Lash and John Urry, The Economies of Sign and Space (London: Sage, 1994); C. Whan Park, Bernard J. Jaworski and Deborah J. MacInnis, 'Strategic brand concept-image management' (1986) 50 Journal of Marketing, October, 135-45; Jonathan E. Schroeder, 'The artist and the brand' (2005) 39 European Journal of Marketing, 1291-1305; and Barbara B. Stern, George M. Zinkhan and Morris Holbrook, 'The netvertising image: image communication model and construct definition' (2002) 31 Journal of Advertising, Fall, $15-28$.
} 
its commercial and artistic production, reception, and recognition, and now dominates how consumers think about identity. ${ }^{2}$

Research on visual consumption has gone through several phases. In the first phase, sociologists such as Erving Goffman and Howard Becker deployed photographs as data, evidence and illustrations within research projects and scholarly reports documenting visual aspects of society. In the second phase, visual images in advertising, branding and corporate identity were seen to reveal and reflect strategic and well as social issues as researchers began to focus on the representational power of images via visual analysis, subject generated images, and photo elicitation techniques. ${ }^{3}$ In the current phase, visual images themselves have assumed central importance, drawing from cultural studies and visual studies disciplines that emerged to interrogate popular cultural forms, and later visual culture. Within this phase, a typical study might investigate how the television sports channel ESPN covers the Olympics, emphasizing the visual technologies that structure information and ideology, or bring a visual perspective to consumer identity, utilizing an interdisciplinary approach beyond the interests of aesthetics or visual studies. ${ }^{4}$

Each phase contains several streams of research, including those that focus on image interpretation from various perspectives, such as psychoanalysis or semiotics. ${ }^{5}$ Others

\footnotetext{
${ }^{2}$ I argue that photography - encompassing film, video, still and digital photography - plays a key role in consumption and branding processes, albeit one that is under-estimated in marketing scholarship: Jonathan E. Schroeder, Visual Consumption (London: Routledge, 2002).

${ }^{3}$ See Theo van Leeuwen and Carey Jewitt (eds), Handbook of Visual Analysis (London: Sage, 2001),; and Jonathan E. Schroeder, 'Critical visual analysis', in Russell W. Belk (ed.), Handbook of Qualitative Research Methods in Marketing (Cheltenham: Edward Elgar, 2006), pp. 303-321.

${ }^{4}$ See, e.g., Janet L. Borgerson and Jonathan E. Schroeder, 'Identity in marketing communications: an ethics of visual representation', in Allan J. Kimmel (ed.) Marketing Communications: Emerging Trends and Developments (Oxford: Oxford University Press, 2005), pp. 256-77; and Eric Guthey and Brad Jackson, 'CEO portraits and the authenticity paradox' (2005) 42 Journal of Management Studies, July, 1057-82.

${ }^{5}$ See Stuart Hall (ed.), Representation: Cultural Representation and Signifying Practices (London: Sage, 1997), for a concise introduction of visual representation in social science.
} 
emphasize image-making as social psychological act of representing and communicating, drawing on traditional anthropological and sociological theories and methods. Another approach utilizes photographs, or other visual artefacts, as stimuli for research, for photoelicitation, akin to projective measures within psychology that investigate deeper meanings and associations that people bring to images. An additional related practice concerns visual presentation of research, documentary films and videos as well as more filmic treatments of consumption topics such as rituals, subcultures, or tourism. In the next section, I present some brief examples of visual analysis of advertising, websites, and corporate communication.

The Transformative Mirror of Consumption

Take in Figure 1 about here

In a recent paper, Schroeder and Zwick ${ }^{6}$ argue that advertising imagery helps consumers resolve cultural contradictions. This study focused on masculinity identity. Within the feminized consumption realm, how might men be represented as consumers, without diminishing their power? How might the male body function to represent consumer goals, such as success, attractiveness, or the good life? They assessed three contemporary advertising exemplars that articulate this set of contradictions, providing illustrative examples for reflecting on masculinity, ontology, and desire. We do not claim that they are representative; rather we argue that they are meaningful, compelling images worthy of close

\footnotetext{
${ }^{6}$ Jonathan E. Schroeder and Detlev Zwick, 'Mirrors of masculinity: representation and identity in advertising images (2004) 7 Consumption Markets \& Culture, 1, 21-51.
} 
analysis. In this way, they follow interpretive work that focuses on a limited range of materials in order to make broader points about representation and identity in visual materials. $^{7}$

'She was impressed that he ordered their Mudslides with Coloma. Which did wonders for his self-confidence' states a recent print ad for Coloma '100\% Colombian Licor de Cafe.' This ad features a black and white photograph of a white man and woman at a bar or restaurant table with a superimposed colour photograph of a Coloma bottle next to a lowball glass that presumably contains a Mudslide drink.

The action takes place in an oval, gilt-framed mirror hanging to the left of the couple. The bespectacled man gazes at his reflection, which has curiously transformed him into a much more classically attractive visage. In the mirror's reflection, the man appears to be in his mid to late twenties, tall, dark, a rakish curl of hair falling seductively down his forehead. He has lost 'his' eyeglasses, pointed nose, unstylish hair, and oversize chin - he might be said to resemble Pierce Brosnan as James Bond. The woman - not caught in the reflection that we see - seems to be peering across her companion to look at his rugged reflection. She models a low cut cocktail dress, which reveals a thin frame, a conservative, shoulder-length haircut, and makeup that exaggerates her facial expression - one of bemusement. She appears to be enjoying herself - her right arm reaches over and grasps the man's right arm. His right hand curls around his Coloma Mudslide, maintaining its fetish-like powers of transformation.

We suggested that the ad represents a portrait of a male-female couple with the addition of another male peering in on them from behind the mirror. This mirrored image may be read in several ways, as the sage from whom the man learned the ways of ordering impressive drinks, or the self transformed by demonstrating taste. To order and consume the

\footnotetext{
${ }^{7}$ This approach calls for an interdisciplinary imagination, like one expressed by art historian Ernst Gombrich in The Uses of Images: Studies in the Social Function of Art and Visual Communication (London: Phaidon, 1999).
} 
right product (even the choice of the restaurant) expresses the man's cultural capital in the field of middle-class consumer culture. Thus, the ornamental femininity of his date further enhances his capital accumulation, and her apparent pleasure at his beverage brand reaffirms his masculinity, attractiveness and taste in one go. Perhaps more attractive mirror-man admires less attractive man's drinking partner, thus conferring male status on his ability to attract a desirable date? The alchemical mirror embodies contradictions of the consuming male; one must be vain and attractive, as well as rational and sophisticated.

Furthermore, the tropes of alcohol involve taste, the pleasures of imbibing, the ability to 'control one's liquor', and, at a more fundamental level, a ritual of adulthood, especially the male variety. In Pierre Bourdieu's theory of symbolic capital, the conversion of one form of capital into another is precisely what makes it so valuable to vie for various forms of capital in different social fields. Here, we see the conversion of cultural capital into social capital by virtue of acquiring more desirable 'body-for-others. ${ }^{8}$ Either way, we have a provocative message of physicality and product use.

The 'homely' man seems caught, Narcissus-like, gazing at his more handsome reflection, looking away from his date. Mirrors are a traditional trope of vanity, narcissism, lust, and pride in Western art. Usually, mirrors are linked to women, revealing, reflecting, and reinforcing feminine attributes of beauty and vanity. In this ad, the mirror plays a double role - casting a reflection of the newly self-confident man, and echoing the female role of mirroring male identity. Thus, the feminine mirrors the masculine, reflecting back selfconfidence, consumer expertise, and embodied transformation. Furthermore, the woman stands in as a mirror. He looks to her to gain a flattering conception of himself - she was impressed which did wonders for his self-confidence. This ad stands out for its representation of the male gaze, and suggests a reordering of limits within the male discourse. The image

\footnotetext{
${ }^{8}$ Pierre Bourdieu, Distinction - A Social Critique of the Judgment of Taste (Cambridge, MA: Harvard University Press, 1984), p. 207.
} 
appears to invert, or perhaps expand, the object of gaze; the man seems quite concerned with himself as an object of beauty, as he vainly pays more attention to his image than to his date. His self-doubts fade - thanks to the woman's positive impression - his masculinity reaffirmed. However, one might read this ad in other ways, as men to men, perhaps the striking man in the mirror attracts the gaze of the homely man, doubly disrupting the gaze, and transforming the ad into a potentially gay image. ${ }^{9}$ This queer perspective finds homoerotic overtones in the gaze between the two men - one reflecting, one reflected - who wink at themselves while wooing others.

A similar visual theme occupies an ad for Gateway computers, The Way Things Should Be. In this example, another apparently unattractive man gazes into a mirrored wall to see a more conventionally good looking 'reflection,' transformed, in this case, by his 'smart, sexy, and always on the go' Gateway notebook computer. His 'improved' reflection has more hair, a more conventionally masculine face, complete with a 'strong' jaw, and his clothes seem to fit him better. As in the Coloma ad, his grasps the talismanic product with his right hand, as he straightens his necktie with his left, perhaps signalling grooming rituals that underlie contemporary notions of masculine regimes of appearance. Here, however, the modernist office environment provides the setting, subtly suggesting that looks count on the job as well as on the make. The classic visual analysis technique of comparing and contrasting helps uncover themes common across product categories and brand campaigns, helping shift our focus to broader cultural concerns than market focused studies, and opening up consumer research to interdisciplinary inquiry.

\footnotetext{
${ }^{9}$ For more on what is known as 'gay vague' branding strategy, which helps illustrate the malleability of brand images, see Barbara B. Stern and Jonathan E. Schroeder, 'Interpretive methodology from art and literary criticism: a humanistic approach to advertising imagery' (1994) 28 European Journal of Marketing, 114-32; and Janet L. Borgerson, Jonathan E. Schroeder, Britta Blomberg and Erika Thorssén, (2006) 'The gay family in the ad: consumer responses to non-traditional families in marketing communications' (2006) 22 Journal of Marketing Management, 955-78.
} 
Architectural Expression in the Electronic Age

Take in Figure 2 about here

In a visual genealogy of contemporary marketing communication and branding efforts, this project analyzed banking Websites, corporate reports, and marketing communication to reveal the staying power of classicism for transmitting certain key values about banks and building brand images for global financial institutions. ${ }^{10}$ This type of study requires interdisciplinary sources, and often a good introductory book from an implicated field offers a useful start - for example, Conway and Roenisch's wonderfully concise Understanding Architecture. ${ }^{11}$ I studied bank websites, financial institution's brand campaigns, credit card advertising, and investment bank's corporate report, and found the classical language of architecture remains, despite massive changes in banking and the financial sector. Although space and time are transfigured within the information based electronic world of contemporary commerce, classical architecture remains a viable method for communicating consumer values.

Architecture has played a key role in persuading consumers about the merits of banks:

Created by private capital to serve a pragmatic function for its owners, bank architecture at the same time turns a public face to its community in a vigorous attempt to communicate, persuade, assure, impress, and convince...Contemporary attitudes regarding money, respectability, security, and corporate aesthetics are

\footnotetext{
${ }^{10}$ See Jonathan E. Schroeder, 'Architectural expression in the electronic age', in Linda M. Scott and Rajeev Batra (eds.), Persuasive Imagery: A Consumer Response Perspective (Mahwah, NJ: Lawrence Erlbaum, 2003), pp. 349-82.

${ }^{11}$ Hazel Conway and Rowan Roenisch, Understanding Architecture (London: Routledge, 2005).
} 
reflected... bank architecture thus communicates the importance of banks as institutions, assuring us of their stability, prosperity, and permanence and inviting us inside to do business. ${ }^{12}$

Architecture provided a strategic method for banks to communicate key attributes of stability, strength, and security. The classical form visually generates 'a sense of longevity, stability, rectitude, even stable power. ${ }^{, 13}$ Customers entrust banks with their savings - this distinguishes banking from most other business concerns. Although most consumers are aware that banks don't store delegate space to store their particular money-money is represented by computer databases now - the physical attributes of the bank have played an important role in projecting a proper image, including stability over time, financial and material strength, and financial and physical security. Classicism helped legitimize banking, a role it played for the nascent nation as a whole:

Classicism, like language, is precise but flexible. It can suggest commercial probity, as we see in the classical architecture of bank buildings and above all, in the New York Stock Exchange. It can radiate culture, as in the neoclassical art museum in Philadelphia and many another city. In the early nineteenth century, the Greek temple form pledged allegiance to the democratic principles that American traced back to ancient Athens. $^{14}$

Each of these strategic banking values — stability, strength, and security—has a psychological dimension as well as a material solution. Stability, expressed in visual form by a sturdy structure, provides a metaphor for long term endurance-'this is why the posts, pillars, and columns which have assured people in many cultures of the buildings' structural

\footnotetext{
${ }^{12}$ Robert Nisbet, 'Men and money: reflections by a sociologist', in Robert Nisbet, Susan Wagg and Anne W. Tucker (eds.), Money Matters: A Critical Look at Bank Architecture (New York: McGraw Hill, 1990), pp. 7-14 at 8.

${ }^{13}$ James F. O'Gorman, A B C of Architecture (Philadelphia: University of Pennsylvania Press, 1998), p. 94.

${ }^{14}$ Ibid, p. 95.
} 
stability have been just as critical in resolving other uncertainties and anxieties. ${ }^{15}$ Colossal columns, heavy materials, and symmetrical form contribute to a building's appearance of strength. Of course, bank customers also desire financial strength, and an ability to withstand economic cycles. Security, for so long largely dependent on architecture fortresses, walled cities, and massive structures, also relates to psychological anxiety about financial matters. The closed form of most banks was meant to signal protection - a secure institution to entrust one's future. Furthermore, the use of the temple form created a visual of a special building protecting its valuables, allowing only certain people access to the interior space, and promoting a ritual element of bank visit. Banks are not just depositories of money; they are repositories of hopes, dreams, and anxieties — a modern temple.

Information technology drove many changes in the banking industry-money and financial matters are no confined to pieces of paper that must be sorted and stored in ways that leave a ledger and an audit trail. Instead, they are electronic entries, generated via computers, and disconnected from particular spaces or buildings. This transformation was instrumental in overhauling the banking system from a loose network of numerous small local banks interacting with the Federal Reserve System to the current deregulated arrangement of mega banks, online banking, and international markets. The small town bank of the past, where customers knew the tellers, and met personally with the loan officer to discuss your mortgage, is gone, replaced by ATM machines, computerized forms, and secondary markets for mortgages. More efficient, certainly, but possibly less human. Perhaps this points to the continuing significance of classical architecture - it alone remains to symbolize banking's connection with the past by tapping into classicism as a powerful referent system. Although the premises of banking have changed, the promises of the banking industry have not.

${ }^{15}$ John Onians, Bearers of Meaning: The Classical Orders in Antiquity, the Middle Ages, and the Renaissance (Princeton, NJ: Princeton University Press, 1988), p. 3. 
A fourth banking attribute emerged along with the electronic revolution-speed. Now banks need to communicate the four S's: Stability, Strength, Security, and Speed, as customers expect quick and efficient transactions supported by computerized operations. However, the other values remain, and basic relationships between the consumer and the bank continue to require symbolic association. The giant Wells Fargo Bank's 1999 annual report announced that 'the basic financial needs of our customers, however, do not change that much. They want to borrow, invest, transact, and be insured. They want convenience, security, trust and dependability. ${ }^{16}$ What role does the classical form play today? Certainly, banks are no longer primarily physical places - they are name brands that occupy space in the consumer's mind. I am not concerned here with recently built banks, or general architectural trends. Rather, I am interested in how the classical form resides in contemporary marketing communication —advertising, corporate reports, web sites, and the ephemera of electronic banking — for these are the crux of brand building and meaning making.

Take in Figure 3 about here

Merrill-Lynch, one of the world's largest investment banking firms, created one of the most visually striking examples of the uses of classicism in contemporary bank advertising. One version of their late 1990s corporate image-building campaign features four Ionic columns in the background of a stylized Grecian amphitheatre ruins. A circular, futuristiclooking podium sits at the centre of the amphitheatre, echoing the its rounded form. Each architectural element appears as a separate photograph, morphed together to create a pastiche of classicism, resembling an ancient site that has been restored by Disney, or assembled for a film set. The golden columns are not supporting anything - they appear to float in the frame,

${ }^{16}$ Well Fargo Bank 1999 Annual Report (San Francisco: Author, 2000), p. 4. 
hovering above the marble amphitheatre's circular steps. Strict classical form demanded an even number of columns - so even these detached, decontextualized columns nod to tradition. On the left side of the two-page spread, there is a quote from Merrill-Lynch's CEO stressing, 'we believe a more vibrant marketplace of ideas will make a difference in addressing the critical challenges of the day.' This somewhat ambiguous statement refers to that decade's deregulation of the finance industry, opening up new markets for banking firms.

The classical elements, abstracted and stylized, appear almost as if they have been cut and pasted from a graphics program, in what architectural historians Tzonis and Lefaivre castigate as 'citationism. 17 The image vaguely resembles an ancient site, but the Ionic columns show no signs of age, nor do the amphitheatre steps - they have been taken out of context and harnessed for Merrill-Lynch's communication needs. The podium clashes with the columns, its sleek form jars the image into the 20th century. Of course, debate flows from the podium, thus the speaker is assumed to be from the current epoch, discussing ideas in a time-honoured tradition, within the classical forum of the amphitheatre. However, the podium also signifies a special position from which to speak, quite different than the open marketplace.

Merrill-Lynch's quote refers to the classical marketplace — the agora — as an ideal for discussing ideas. However, the image shows an amphitheatre - the domain of actors-only certain people spoke in plays. Merrill-Lynch portrays itself within the foundation of free society, equating open markets with open dialogue, freedom with financial freedom, and democracy with capitalism, but a close analysis of this ad reveals misplaced agency, confusing the scripted world of the theatre with the agora. Furthermore, the classical motifs help Merrill-Lynch project a stable, strong, and secure image - yet one that is flexible,

\footnotetext{
${ }^{17}$ Alexander Tzonis and Liane Lefaivre, Classical Architecture: The Poetics of Order (Cambridge, MA: MIT Press, 1986).
} 
adaptive to new environments, and able to accommodate new forms, as the contemporary podium attests.

Using the shorthand of architecture language, which refers to classical forms, the Greek ideal, the marketplace of ideas, and the roots of Western democracy, Merrill-Lynch produced a complex advertising image, simply realized. Their business, then, is not limited to financial matters - they deal in ideas, which require testing via dialogue and debate. Architecture functions as a heuristic for consumers in a cluttered marketplace of images. It is not necessary for viewers to identify columns as 'Ionic' or 'Doric,' or know much about the history of classicism for this ad to work as a reference to tradition, dialogue and debate, and the classical past. By juxtaposing old and new styles, Merrill-Lynch sets up an implicit contrast as well as an allusion to time.

Traditionally, consumers have valued three qualities in a bank: stability, strength, and security. Banks adopted classical architectural form to persuade the public. In the electronic age, architecture no longer confines banking, nor do most consumer banking transactions take place within a bank's headquarters. Therefore, a change might be expected in communicative tools, classical motifs might seem outmoded or old-fashioned for the information society. However, banks have shifted the symbolic domain from the building to the marketing message, adopting architectural symbols for use in digitized images that carry on the communicative tradition of classical forms. Advertising, Internet sites, and ATM banking still incorporate abstracted architectural symbols, and buildings continue to provide many metaphors for the banking industry. VeriSign - an online financial security firm echoes these architectural themes in their brand communications, which include classical buildings. Furthermore, the ad copy refers to the brand promise of stability, strength and security:

You trust that the ravages of 400 years have not weakened the bases. 
You trust the granite bases to support the 24-foot high Corinthian columns.

You trust nothing more than eight columns to sustain a 15,000-ton dome above your head.

Yet you're wary of using a credit card online?

Thus, the high-tech, electronic VeriSign brand invokes the legacy of the classical form in a neat comparative statement that marries the old and the new, placing an Internet business within the long legacy of architectural signification.

Banks today are in the business of building brands as much as physical structures. Benôit Heilbrunn argues that brands are transformative devices which allow contradictory principles to coincide, such as nature and culture, the real and the imaginary, the past and the present, and the very distant and the here and now. ${ }^{18}$ Classicism reinforces this notion, linking an ancient past to the present via rhetorical devices perfected during in classical era. Of course, these persuasive visual rhetorical tools are augmented via marketing information technology, selling the past to the future. ${ }^{19}$

Classicism remains a central cultural referent structure. Architecture provides spatial, historical, and psychological images easily appropriated by visual media. Furthermore, architecture is a basic metaphorical structure for perception and cognition —indeed, it 'presents embodiments of thought when it invents and builds shapes. ${ }^{20}$ These shapes, translated into two dimensions, abstracted and isolated, are the building blocks of meaning making. By tracing visual genealogies such as classicism, we gain an appreciation of the complex composition of current branding strategies.

${ }^{18}$ See Benoit Heilbrunn, 'Cultural branding between utopia and a-topia', in Jonathan E. Schroeder and Miriam Salzer-Mörling (eds.), Brand Culture (London: Routledge, 2006), pp. 103-117.

${ }^{19}$ As discussed by John Berger in Ways of Seeing (London: Penguin, 1972).

${ }^{20}$ Rudolf Arnheim, The Dynamics of Architectural Form (Berkeley: University of California Press, 1977), p. 274. 
Take in Figure 4 about here

Conclusion: Interdisciplinary insights into Brand Culture

Greater awareness of the associations between the traditions and conventions of visual history and the production and consumption of images helps to position and understand marketing as a global representational system. Research that extends previous work on visual representation into past, cultural, and art historical realms, may provide an essential bridge between visual meaning residing within producer intention or wholly subsumed by individual response, and between aesthetics and ethics. ${ }^{21}$ In other words, along with brand identity and brand image, the realm of brand culture serves as a necessary complement to understanding brand meaning. ${ }^{22}$

Take in Figure 5 about here

To more fully understand brands, researchers must investigate the cultural, historical and representational conventions that shape consumption. If brands exist as cultural, ideological, and political objects, then brand researchers require tools developed to understand culture, politics, and ideology, in conjunction with more typical branding concepts, such as equity, strategy, and value. Brand culture refers to the cultural influences and implications of brands in two ways. First, we live in a branded world: brands infuse culture with meaning, and brand management exerts a profound influence on contemporary

${ }^{21}$ See for example, Steve Charters, 'Aesthetic products and aesthetic consumption: a review,' (2006) 9 Consumption Markets \& Culture, 3, 235-55, and Daragh O'Reilly, 'Cultural brands/branding cultures,' (2005) 21 Journal of Marketing Management, 573-88.

${ }^{22}$ Brand culture represents one interdisciplinary framework for understanding how brands create value and meaning. For further discussion, see Schroeder and Salzer-Mörling, Brand Culture. 
society. Second, brand culture provides a third leg for brand theory - in conjunction with brand identity and brand image, brand culture provides the necessary cultural, historical and political grounding to understand brands in context. Future consumer research on visual issues must acknowledge images' representational and rhetorical power both as cultural artefacts and as engaging and deceptive bearers of meaning, reflecting broad societal, cultural, and ideological codes.

Brand research focused on the political, social and economic implications of images, fuelled by an understanding of the historical conditions influencing their production and consumption may require interdisciplinary training and collaboration. Branding's reliance on images, and implicit claims that images make, often elude regulatory understandings or how brands work. Moreover, typical theories of brand management consistently over emphasize information, product information, and persuasive mechanisms of brand communication; neglecting the powerful roles that visual representation plays in brand strategy. Key questions remain about the relationships between vision and value - why certain images are successful, superfluous, or sacrosanct. Understanding the role that visual consumption plays in consumer preference, cultural production, and representation signals a step toward understanding how the aesthetics, images and vision informs and influences basic consumer issues of attention, branding, identity, and meaning making. 


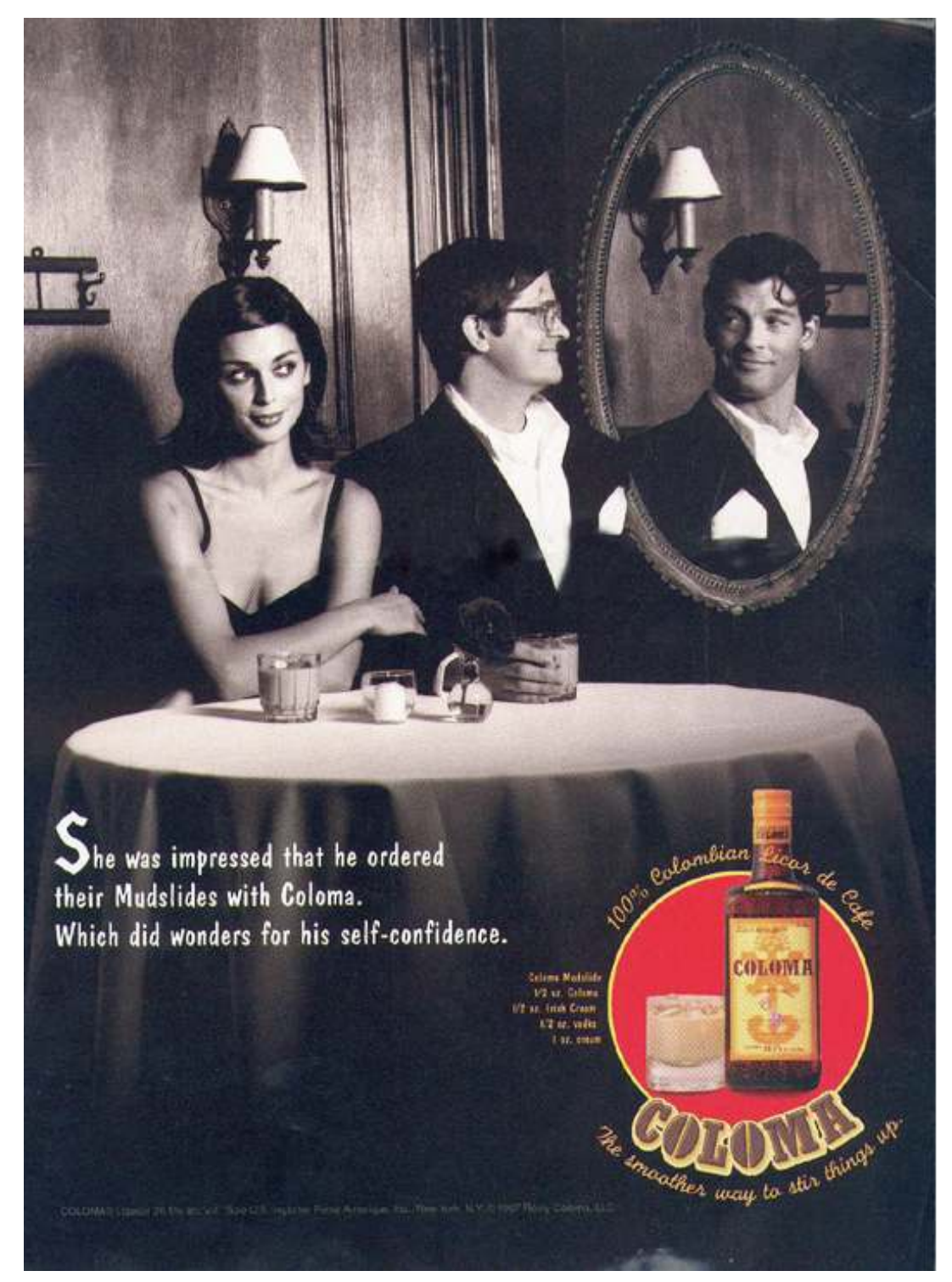

Figure 1 Coloma advertisement, c. 1999 


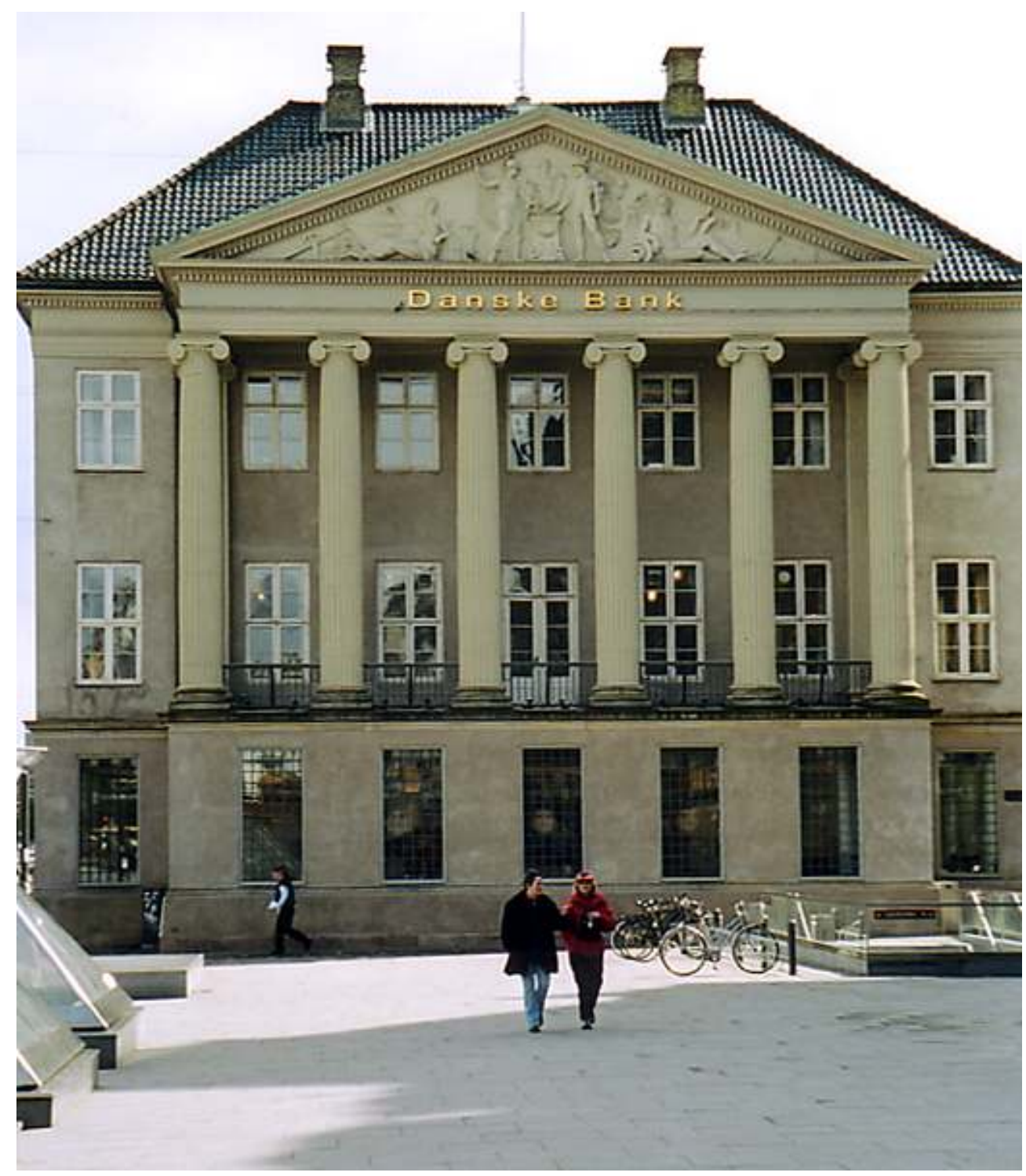

Figure 2 Classical Architectural Imagery from Danske Bank, Copenhagen (photo by Jonathan Schroeder) 


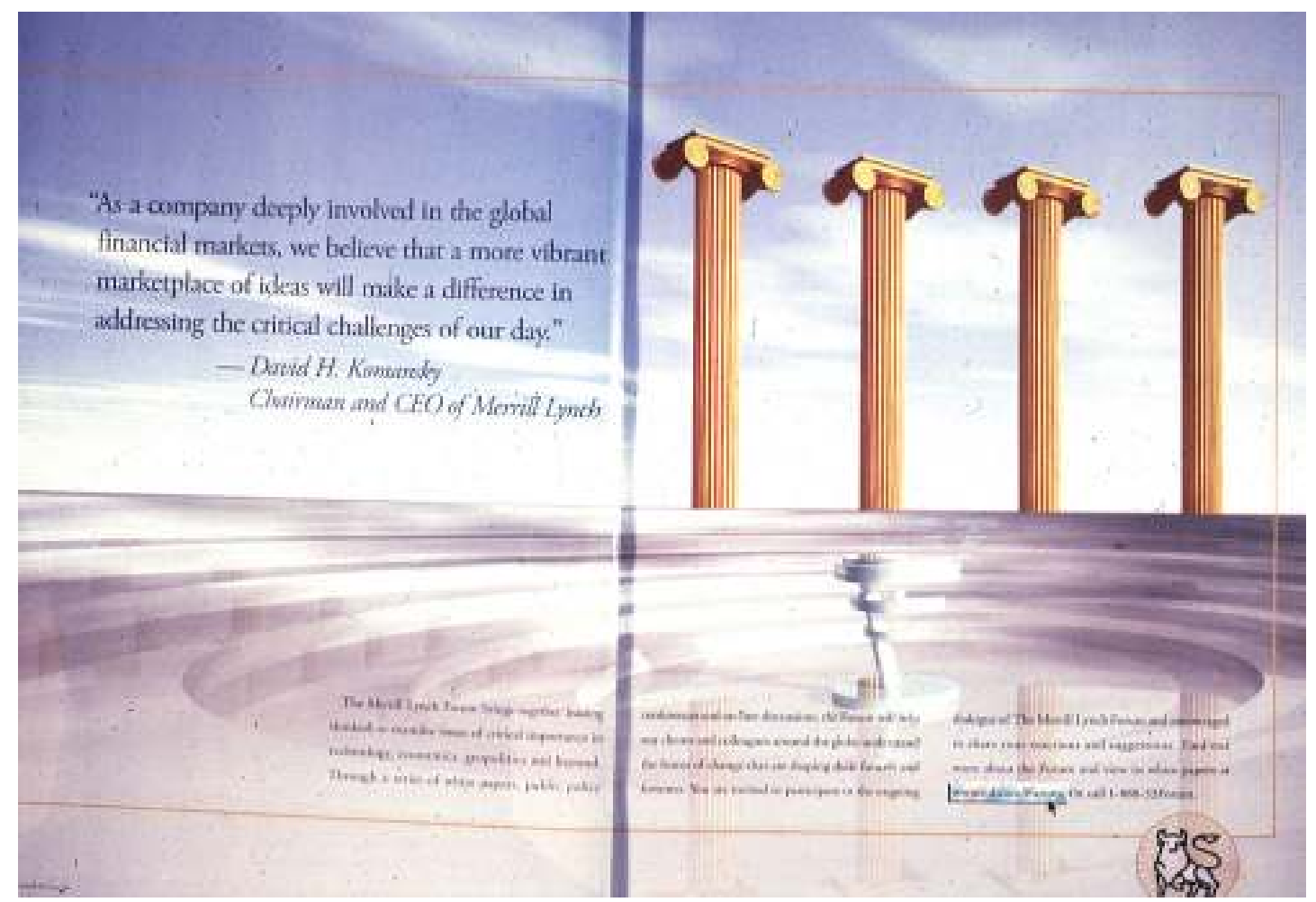

Figure 3 Merrill-Lynch advertisement, c. 1998

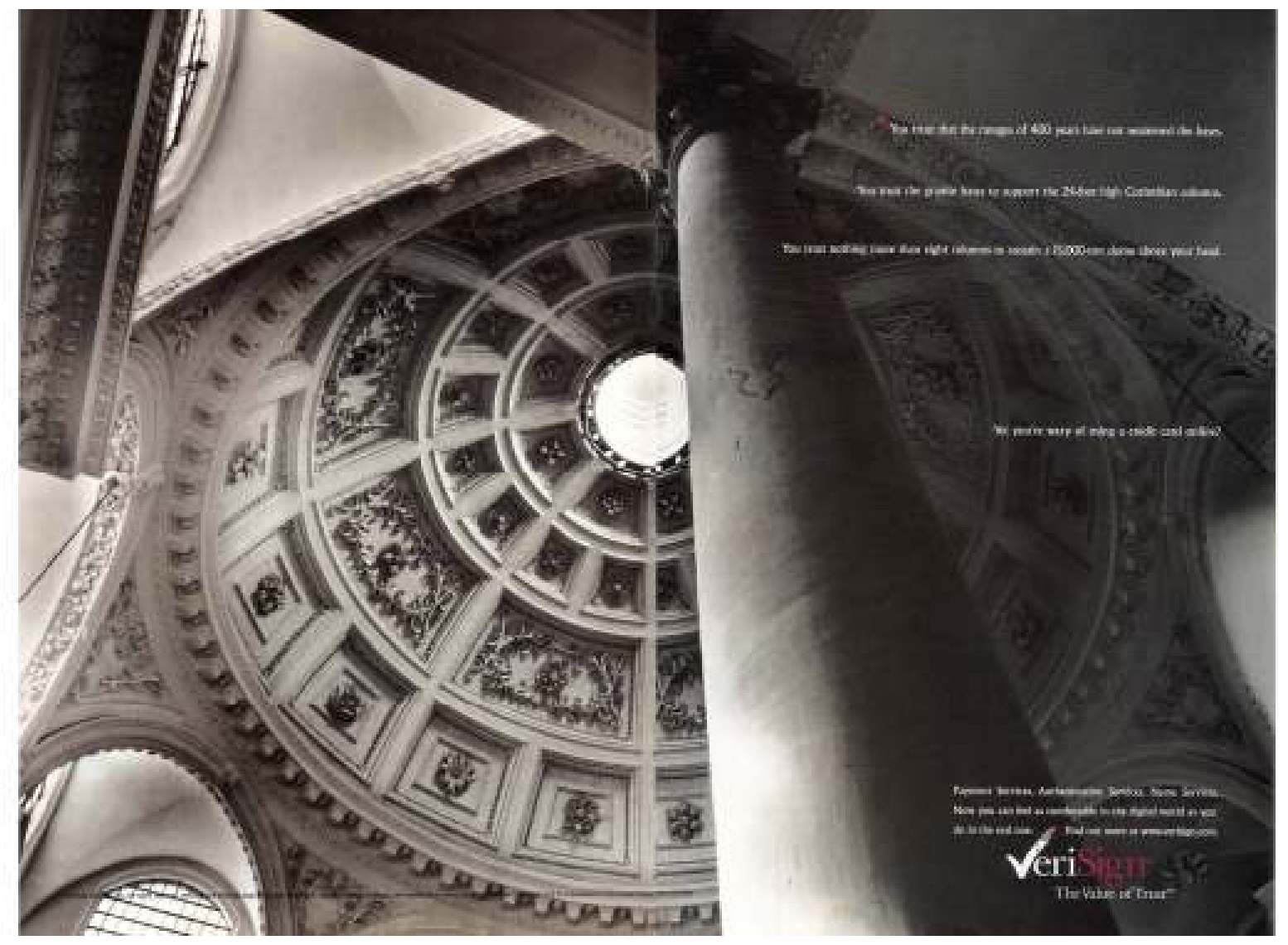

Figure 4 Architectural Referents from VeriSign, an online financial security firm, c. 2003 


\section{Brand Dimensions}

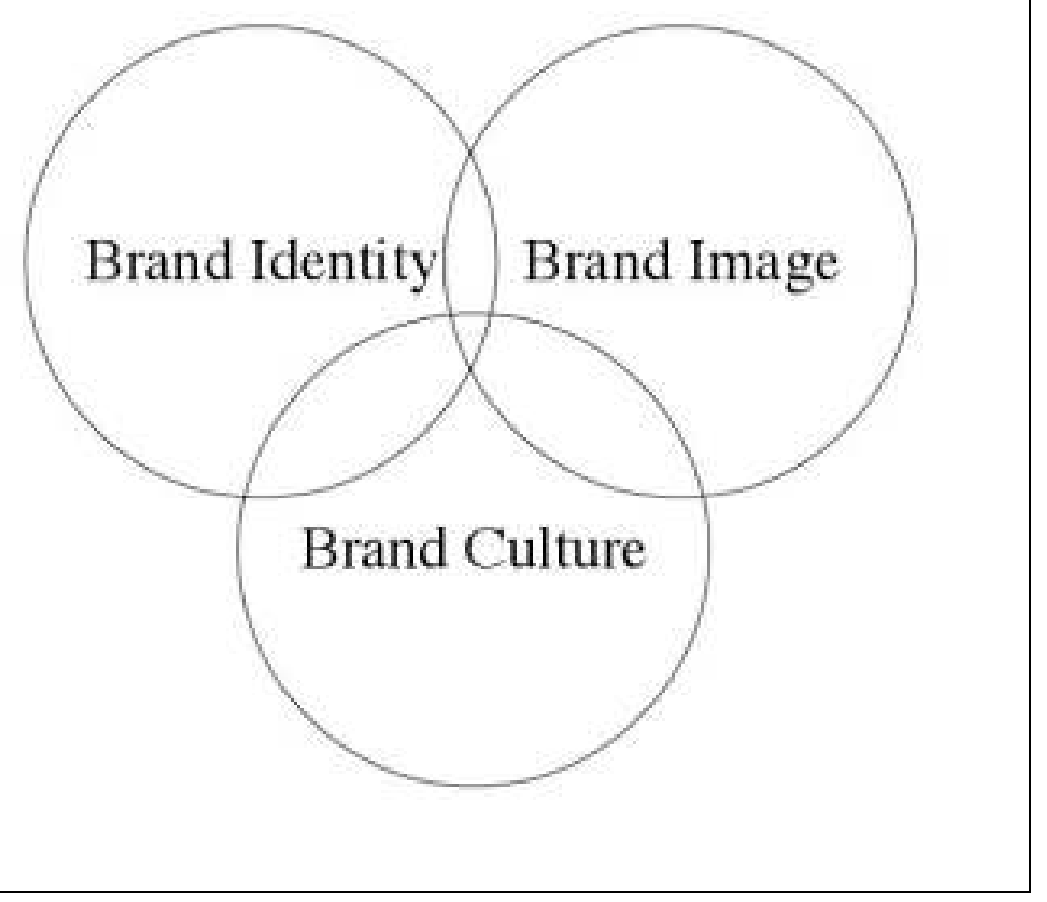

Figure 5 Dimensions of Brand Culture

Bibliography

Arnheim, Rudolf, The Dynamics of Architectural Form (Berkeley: University of California Press, 1977)

Berger, John, Ways of Seeing (London: Penguin, 1972) 
Borgerson, Janet L. and Schroeder, Jonathan E. 'Identity in marketing communications: an ethics of visual representation', in Allan J. Kimmel (ed.) Marketing Communications: Emerging Trends and Developments (Oxford: Oxford University Press, 2005), pp. $256-77$

Borgerson, Janet L., Schroeder, Jonathan E., Blomberg, Britta and Thorssén, Erika, 'The gay family in the ad: consumer responses to non-traditional families in marketing communications’' (2006) 22 Journal of Marketing Management, 955-78

Bourdieu, Pierre, Distinction - A Social Critique of the Judgment of Taste (Cambridge, MA: Harvard University Press, 1984)

Charters, Steve, 'Aesthetic products and aesthetic consumption: a review,' (2006) 9 Consumption Markets \& Culture, 3, 235-55

Conway, Hazel and Roenisch, Rowan, Understanding Architecture (London: Routledge, 2005)

Gombrich, Ernst, The Uses of Images: Studies in the Social Function of Art and Visual Communication (London: Phaidon, 1999)

Guthey, Eric and Jackson, Brad, 'CEO portraits and the authenticity paradox' (2005) 42 Journal of Management Studies, July, 1057-82

Hall, Stuart (ed.), Representation: Cultural Representation and Signifying Practices (London: Sage, 1997)

Heilbrunn, Benoît, 'Cultural branding between utopia and a-topia', in Jonathan E. Schroeder and Miriam Salzer-Mörling (eds.), Brand Culture (London: Routledge, 2006), pp. $103-117$

Lash, Scott and Urry, John, The Economies of Sign and Space (London: Sage, 1994) 
Nisbet, Robert, 'Men and money: reflections by a Sociologist', in Robert Nisbet, Susan Wang, and Anne W. Tucker (eds.), Money Matters: A Critical Look at Bank Architecture (New York: McGraw Hill, 1990), pp. 7-14

O'Gorman, James F. A B C of Architecture (Philadelphia: University of Pennsylvania Press, 1998)

Onians, John, Bearers of Meaning: The Classical Orders in Antiquity, the Middle Ages, and the Renaissance (Princeton, NJ: Princeton University Press, 1988)

O’Reilly, Daragh, 'Cultural brands/branding cultures,' (2005) 21 Journal of Marketing Management, 573-88

Park, C, Whan, Jaworski, Bernard J. and MacInnis, Deborah J. 'Strategic brand conceptimage management' (1986) 50 Journal of Marketing, October, 135-45

Schroeder, Jonathan E. Visual Consumption (London: Routledge, 2002)

Schroeder, Jonathan E. and Zwick, Detlev, 'Mirrors of masculinity: representation and identity in advertising images (2004) 7 Consumption Markets \& Culture, 1, 21-51

Schroeder, Jonathan E. 'Architectural expression in the electronic age', in Linda M. Scott and Rajeev Batra (eds.), Persuasive Imagery: A Consumer Response Perspective (Mahwah, NJ: Lawrence Erlbaum, 2003), pp. 349-82

Schroeder, Jonathan E. 'The artist and the brand' (2005) 39 European Journal of Marketing, $1291-1305$

Schroeder, Jonathan E. 'Critical visual analysis', in Russell W. Belk (ed.), Handbook of Qualitative Research Methods in Marketing (Cheltenham: Edward Elgar, 2006), pp. 303-321

Schroeder, Jonathan E. and Salzer-Mörling, Miriam (eds.), Brand Culture (London: Routledge, 2006) 
Stern, Barbara B. and Schroeder, Jonathan E. 'Interpretive methodology from art and literary criticism: a humanistic approach to advertising imagery' (1994) 28 European Journal of Marketing, 114-32

Stern, Barbara B. George M. Zinkhan, George M. and Holbrook, Morris, 'The netvertising image: image communication model and construct definition' (2002) 31 Journal of Advertising, Fall, 15-28

Tzonis, Alexander and Lefaivre, Liane, Classical Architecture: The Poetics of Order (Cambridge, MA: MIT Press, 1986)

van Leeuwen, Theo and Jewitt, Carey (eds), Handbook of Visual Analysis (London: Sage, 2001)

Well Fargo Bank 1999 Annual Report (San Francisco: Author, 2000) 